\title{
AIR QUALITY OF KARAMAN CITY, TURKEY
}

\author{
Hysen Mankolli ${ }^{1}$, Huseyin Toros ${ }^{2}$, Sukru Dursun ${ }^{3 *}$ \\ ${ }^{1}$ NOAA/OAR project, University of Maryland College Park, USA; \\ ${ }^{2}$ Istanbul Technical University, Faculty of Aeronautics and Astronautics, Department of Meteorology, \\ Maslak, Istanbul, Turkey; \\ ${ }^{3 *}$ Konya Technical University, Engineering and Natural Science Faculty, Environmental Engineering \\ Department, Konya, Turkey;
}

*Corresponding Author Sukru Dursun, e-mail: sdursun@ktun.edu.tr; toros@itu.edu.tr; hysenmankolli@yahoo.com;

Received May 2020; Accepted June 2020; Published July 2020;

DOI: https://doi.org/10.31407/ijees10.309

\begin{abstract}
Karaman is a new and developing city in Turkey's economy is developing and the industry. Geographically, the location of Karaman is located in the south of the Central Anatolia region, in the north of the Taurus Mountains. With its fertile lands, the economy and industry based on Karaman agriculture are developing. Karaman city center has modern industrial facilities open for employment. It is known to have an important industrial potential in recent years. The total surface area of 887 thousand ha of Karaman province; 229 thousand hectares (26\%) are flat areas and 654 thousand hectares (74\%) are mountainous. The population size is around 250 thousand. Turkey is ahead in the production of bakery products, $35 \%$ and $20 \%$ of total wheat production is produced by Karaman biscuit manufacturing industry. Turkey, as in general in Karaman in fossil fuel consumption for heating in the cold winter air pollution as it is used in many developed cities is also observed. Traffic vehicles vehicle exhausts and fossil fuels used in industry are other important sources of pollution in the city center. In Turkey, the year 2020 at the beginning of March with the gorilla-19 Covidien epidemic, there has been a significant improvement in air quality. The field dust event that occurred after pandemic virus measures, especially PM pollution increase was observed.
\end{abstract}

Keywords: Air quality, Pollution, Karaman province, Covidien-19 measure, 